\title{
PENGARUH GAYA KEPEMIMPINAN, KOMUNIKASI INTERNAL DAN MOTIVASI KERJA PADA KINERJA KARYAWAN PERBANKAN DI PURWOKERTO
}

\author{
PURNADI \\ Universitas Muhammadiyah Purwokerto
}

\begin{abstract}
ABSTRAK
Manajemen dan organisasi bukan tujuan, tetapi hanya alat untuk mencapai tujuan yang diinginkan, karena tujuan yang ingin dicapai itu adalah pelayanan dan atau laba (profit). Walaupun menajemen dan organisasi hanya perupakan "alat dan wadah" saja tetapi harus diatur dengan sebaik-baiknya. Organisasi adalah sebuah unit sosial yang dikoordinasikan secara sadar yang terdiri atas dua orang atau lebih dan berfungsi dalam suatu dasar yang relatif terus-menerus guna mencapai suatu tujuan bersama (Robbins: 2008).
\end{abstract}

Kata Kunci : perbankan, organisasi, sdm

\section{Pendahuluan}

Organisasi dalam mencapai tujuannya, membutuhkan peran penting dari sumber daya manusia sebagai salah satu faktor internal. Sumber daya manusia dalam suatu organisasi perlu diarahkan melalui pengelolaan sumber daya manusia yang baik.

Pengelolaan sumber daya manusia yang dimaksudkan adalah organisasi harus mampu untuk menyatukan persepsi atau cara pandang pegawai dan pimpinan organisasi dalam rangka mencapai tujuan organisasi antara lain melalui pembentukan mental bekerja yang baik, memberikan motivasi kerja, bimbingan, pengarahan dan koordinasi yang baik dalam bekerja oleh seorang pemimpin kepada para pegawainya. Pada umumnya kinerja diartikan sebagai kesuksesan seseorang dalam melaksanakan suatu pekerjaan. Kinerja individu dengan kinerja organisasi terdapat hubungan yang erat, dengan kata lain bila kinerja karyawan baik maka kemungkinan besar kinerja organisasi juga baik. Dalam suatu organisasi, pemimpin merupakan salah satu faktor penting karena faktor kepemimpinan dapat memberikan pengaruh yang berarti terhadap kinerja karyawan. Gaya kepemimpinan adalah pola tindakan pemimpin secara keseluruhan seperti yang dipersepsikan oleh para pegawainya, Davis (1985). Dalam melaksanakan pekerjaan, karyawan juga tidak terlepas dari suatu komunikasi baik komunikasi dengan pimpinan maupun komunikasi dengan sesama rekan kerja. Komunikasi merupakan unsur yang penting dalam kehidupan organisasi, baik ditinjau dari segi proses administrasi dan manajemen maupun keterlibatan semua pihak didalam suatu organisasi. Disamping itu, motivasi kerja juga sangat diperlukan bagi karyawan untuk meningkatkan kinerjanya. Sujak (1990), pemahaman motivasi baik yang ada dalam diri karyawan maupun yang berasal dari lingkungan akan dapat membantu dalam peningkatan kinerja.

\section{Gaya Kepemimpinan}

Definisi kepemimpinan secara luas meliputi proses mempengaruhi dalam menentukan tujuan organisasi, memotivasi perilaku pengikut untuk mencapai tujuan, mempengaruhi untuk memperbaiki kelompok dan budayanya. Dubrin (2005) menyatakan bahwa kepemimpinan itu adalah upaya mempengaruhi banyak orang melalui komunikasi untuk mencapai tujuan, cara mempengaruhi orang dengan 
petunjuk atau perintah, tindakan yang menyebabkan orang lain bertindak atau merespon dan menimbulkan perubahan positif, kekuatan dinamis penting yang memotivasi dan mengkoordinasikan organisasi dalam rangka mencapai tujuan, kemampuan untuk menciptakan rasa percaya diri dan dukungan diantara bawahan agar tujuan organisasional dapat tercapai.

Gaya kepemimpinan adalah perilaku dan strategi sebagai hasil kombinasi dari falsafah, keterampilan, sifat, sikap yang sering diterapkan seorang pemimpin. Davis (1985) menyatakan bahwa gaya kepemimpinan adalah pola tindakan pemimpin secara keseluruhan seperti yang dipersepsikan oleh pegawainya. Menurut House (1971), terdapat 4 macam gaya kepemimpinan, yaitu:

1. Kepemimpinan Direktif

Memberikan panduan kepada para karyawan mengenai apa yang seharusnya dilakukan dan bagaimana cara melakukannya, menjadwalkan pekerjaan dan mempertahankan standar kinerja.

2. Kepemimpinan Suportif

Menunjukkan kepedulian terhadap kesejahteraan dan kebutuhan karyawan, bersikap ramah dan dapat didekati serta memperlakukan para pekerja sebagai orang yang setara dengan dirinya.

3. Kepemimpinan Partisipatif

Berkonsultasi dengan para karyawan dan secara serius mempertimbangkan gagasan mereka pada saat pengambilan keputusan.

4. Kepemimpinan yang berorientasi pada pencapaian

Mendorong para karyawan untuk berprestasi pada tingkat tertinggi mereka dengan menetapkan tujuan yang menantang, menekankan pada kesempurnaan dan memperlihatkan kepercayaan diri atas kemampuan karyawan.

\section{Komunikasi Internal}

Istilah komunikasi berasal dari bahasa latin "communicatio" dan perkataan ini bersumber pada kata "communis", mengandung arti yang sama, maksudnya sama makna. Aliran informasi di suatu organisasi dibagi menjadi dua dimensi yakni komunikasi secara internal dan eksternal.

Komunikasi internal adalah proses penyampaian pesan yang berlangsung antar anggota organisasi, dapat berlangsung antara pimpinan dengan bawahan, pimpinan dengan pimpinan, maupun bawahan dengan bawahan. Muhammad (2001) menyatakan bahwa komunikasi internal adalah komunikasi yang dikirimkan kepada anggota dalam suatu organisasi dengan kata lain penerima pesan dalam komunikasi internal adalah orang-orang dalam organisasi. Komunikasi merupakan bagian yang penting dalam kehidupan kerja suatu organisasi. Hal ini dapat dipahami sebab komunikasi yang tidak baik mempunyai dampak yang luas terhadap kehidupan organisasi, misalnya konflik antar pegawai. Sebaliknya, komunikasi yang baik dapat meningkatkan saling pengertian, kerjasama dan kepuasan kerja. Oleh karena itu, hubungan komunikasi yang terbuka harus diciptakan dalam organisasi. Muhammad (2001) menyatakan bahwa terdapat 3 bentuk komunikasi internal yaitu.

1. Komunikasi Kebawah (Downward Communication), yaitu komunikasi yang bergerak dari pimpinan ke bawahan. Tiap komunikasi yang mengalir dari pimpinan puncak hingga ke bawah mengikuti hierarki adalah komuniksi kebawah.

Tipe-tipe komunikasi kebawah dapat diklasifikasikan sebagai berikut:

a. Instruksi tugas

Instruksi tugas atau pekerjaan yaitu pesan yang disampaikan kepada bawahan mengenai apa yang diharapkan dilakukan mereka dan bagaimana 
melakukannya. Pesan itu dapat berupa perintah langsung, deskripsi tugas, prosedur manual dan program latihan tertentu.

b. Rasional

Rasional pekerjaan adalah pesan yang menjelaskan mengenai tujuan aktivitas dan bagaimana kaitan aktivitas itu dengan aktivitas lain dalam organisasi atau obyek organisasi. Kualitas dan kuantitas dari komunikasi rasional ditentukan oleh filosofi dan asumsi pemimpin mengenai bawahannya.

c. Ideologi

Pesan mengenai ideologi ini adalah perluasan dari pesan rasional. Pesan rasional penekanannya ada pada penjelasan tugas dan kaitannya dengan perspektif organisasi, sedangkan pada pesan ideologi sebaliknya mencari sokongan dan antusian dari anggota organisasi guna memperkuat loyalitas, moral dan motivasi.

d. Informasi

Pesan informasi dimaksudkan untuk memperkenalkan bawahan dengan praktik-praktik organisasi, peraturan-peraturan organisasi, kebiasan dan data lain yang tidak berhubungan dengan instruksi dan rasional.

e. Balikan

Balikan adalah pesan yang berisi informasi mengenai ketepatan individu dalam melakukan pekerjaan. Salah satu bentuk sederhana dari balikan ini adalah apabila pimpinan tidak mengkritik pekerjaannya, berarti pekerjaannya sudah memuaskan.

2. Komunikasi Keatas (Upward Communication)

Adalah arus komunikasi yang bergerak dari bawah ke atas. Pesan yang disampaikan antara lain laporan pelaksanaan pekerjaan, keluhan karyawan, sikap dan perasaan karyawan tentang beberapa hal, pengembangan prosedur dan teknik, informasi tentang produksi dan hasil yang dicapai. Jika arus informasi keatas tidak lancar maka manajemen tingkat atas atau pimpinan kurang mengetahui dan menyadari secara tepat keadaan organisasi pada umumnya.

Komunikasi keatas mempunyai beberapa fungsi atau nilai tertentu sebagai berikut:

a. Dengan adanya komunikasi keatas

pimpinan dapat mengetahui kapan bawahannya siap untuk diberi informasi dari mereka dan

bagaimana baiknya pimpinan menerima apa yang disampaikan karyawan.

b. Arus komunikasi keatas memberikan informasi yang berharga bagi pembuat keputusan.

c. Komunikasi keatas memperkuat apresiasi dan loyalitas bawahan terhadap organisasi dengan jalan memberikan kesempatan untuk menanyakan pertanyaan mengajukan ide-ide dan saran-saran tentang jalannya organisasi.

3. Komuniksi Horisontal (HorizontalCommunication)

Komunikasi horisontal ini sangat intern dilakukan antar bagian yang memiliki tingkat sekuensi kerja yang tinggi, yang dimaksudkan untuk menghemat waktu dan memudahkan melakukan koordinasi yang dapat berlangsung secara formal (hubungan-hubungan kerja dalam pembagian struktur kerja diatur secara formal atau secara informal untuk mempercepat tindakan. 
Komunikasi horisontal mempunyai tujuan tertentu diantaranya sebagai berikut:

a. Mengkoordinasikan tugas-tugas. Bagian-bagian tertentu yang sama jenjangnya dalam organisai kadangkadang perlu mengadakan rapat atau pertemuan untuk mendiskusikan hal-hal yang memberikan kontribusi dalam mencapai tujuan organisasi.

b. Menjamin pemahaman yang sama. Bila perubahan dalam suatu organisasi diusulkan maka perlu ada pemahaman yang sama dari semua komponen yang ada dalam organisasi.

c. Mengembangkan sokongan interpersonal. Karena sebagian besar dari waktu kerja adalah berinteraksi dengan teman untuk memperoleh sokongan hubungan interpersonal dari temannya.

\section{Motivasi Kerja}

Motivasi berasal dari kata motif (motive) yang berarti dorongan, sebab atau alasan seseorang untuk melakukan sesuatu. Gibson et al. (1996) menyatakan bahwa motivasi merupakan konsep yang digunakan untuk menggambarkan dorongandorongan yang timbul pada atau dalam diri seorang individu yang kemudian menggerakkan dan mengarahkan perilakunya. Menurut Maslow (1994), motivasi kerja seorang karyawan akan berpengaruh terhadap kinerja yang dapat dicapai murni hanya timbul dari dalam diri seorang karyawan (motivasi internal) ataukah motivasi berasal dari luar karyawan yang bersangkutan (motivasi eksternal). Menurut Zainun (2004), motivasi dapat dipandang sebagai bagian integral dari administrasi kepegawaian dalam rangka proses pembinaan, pengembangan dan pengarahan tenaga kerja dalam suatu organisasi.

\section{Teori Hierarki Kebutuhan Abraham Maslow}

Inti dari teori ini adalah kebutuhan itu tersusun dalam bentuk hierarki atau penjenjangan. Menurut Lussier (1996), kebutuhan manusia yang dikembangkan oleh Abraham Maslow diklasifikasikan atas lima tingkat dan masing-masing dijelaskan sebagai berikut.

1. Kebutuhan Fisiologis (Physiological Needs), merupakan hierarki kebutuhan paling dasar yang merupakan kebutuhan untuk dapat hidup seperti makan, tempat tinggal dan pakaian yang dapat dipenuhi dengan gaji yang diterima.

2. Kebutuhan Keamanan dan Keselamatan Kerja (Security and Safety Needs), kebutuhan ini meliputi keamanan, keselamatan kerja dan kelangsungan pekerjaan, serta jaminan hari tua.

3. Kebutuhan Sosial (Social Needs), yaitu kebutuhan persahabatan, afiliasi dan interaksi yang lebih erat dengan orang lain. Dalam organisasi akan berkaitan dengan kebutuhan akan adanya kelompok kerja yang kompak.

4. Kebutuhan Penghargaan (Esteem Needs), meliputi keinginan untuk dihormati, dihargai atas prestasi yang dicapai, pengakuan atas kemampuan dan keahlian.

5. Kebutuhan Aktualisasi Diri (Self Actualization Needs), merupakan hierarki kebutuhan yang paling tinggi. Aktualisasi diri berkaitan dengan proses pengembangan akan potensi yang sesungguhnya dari seseorang. Kebutuhan untuk menunjukkan kemampuan, keahlian dan potensi diri.

\section{Teori ERG Alderfer}

Teori motivasi yang dikemukakan oleh Clayton P. Alderfer dijadikan dasar teori yang digunakan dalam penelitian ini. Menurut George dan Jones (2002), Teori Alderfer mengemukakan bahwa ada tiga kebutuhan manusia yang perlu dipuaskan sebagai 
sumber motivasi kerja dan ini untuk melengkapi teori yang dikemukakan oleh Maslow, yaitu.

1. Kebutuhan akan keberadaan (Existence Needs), berhubungan dengan kebutuhan dasar termasuk didalamnya Physiological Needs dan Safety Needs dari Maslow.

2. Kebutuhan akan hubungan (Relatedness Needs), menekankan akan pentingnya hubungan antar individu (interpersonal relationship) dan bermasyarakat (social relationship).

3. Kebutuhan akan pertumbuhan (Growth Needs), dalam keinginan intrinsic dalam diri seseorang untuk maju atau mengingatkan kemampuan untuk maju atau meningkatkan kemampuan pribadinya.

\section{Kinerja}

Kata kinerja merupakan terjemahan dari performance dalam bahasa inggris, artinya pertunjukkan, pembuatan, daya guna, prestasi dan hasil. Menurut Sentono (1999), kinerja adalah hasil kerja yang dapat dicapai oleh seseorang atau kelompok dalam suatu organisasi sesuai dengan wewenang dan tanggung jawab masing-masing dalam rangka upaya mencapai tujuan organisasi yang bersangkutan secara legal, tidak melanggar hukum dan sesuai dengan moral maupun etika. Mangkunegara (2007) menyatakan bahwa kinerja karyawan adalah hasil kerja secara kualitas dan kuantitas yang dicapai oleh seseorang karyawan dalam melaksanakan tugasnya sesuai dengan tanggung jawab yang diberikan kepadanya. Menurut Donnely et al. (1996), kinerja merujuk kepada tingkat keberhasilan dalam melaksanakan tugas serta kemampuan untuk mencapai tujuan yang telah ditetapkan. Menurut Sentono (1999) menyatakan bahwa ukuran-ukuran yang digunakan dalam penilaian kinerja yaitu sebagai berikut:

1. Kualitas pekerjaan

Kualitas pekerjaan meliputi pemahaman dan penguasaan tugas, kebutuhan terhadap instruksi-instruksi pelaksanaan tugas, kemampuan dalam memecahkan masalah, ketelitian dalam tugas, efisiensi waktu, tenaga dan biaya dalam melaksanakan tugas, ketekunan dan kedisiplinan dalam melaksanakan tugas, kemampuan dalam bekerja sendiri, tanggung jawab, kepemimpinan, kecakapan dalam menggunakan peralatan, kemampuan memperbaiki peralatan kerja.

2. Kuantitas pekerjaan

Kuantitas pekerjaan meliputi kemampuan menyelesaikan seluruh pekerjaan yang ditugaskan dan

kemampuan untuk menyelesaikan pekerjaan melebihi yang ditugaskan.

3. Ketepatan waktu kerja

Ketepatan waktu kerja meliputi ketepatan waktu dalam menyelesaikan tugas, ketepatan waktu dalam kehadiran, ketepatan waktu dalam istirahat dan pulang kantor dan tingkat kehadiran.

4. Kerjasama dengan rekan kerja

Kerjasama dengan rekan kerja meliputi kemampuan bekerjasama didalam kelompok, kemampuan bekerja diluar kelompok, kemampuan menjalin komunikasi dengan atasan dan kemampuan memberi bimbingan dan penjelasan kepada karyawan lini.

\section{Kerangka Pemikiran dan Hipotesis}

H1 : Gaya kepemimpinan, komunikasi internal dan motivasi kerja secara simultan berpengaruh signifikan terhadap kinerja pegawai kantor Kecamatan Grogol Petamburan Jakarta Barat. 
H2 : Gaya kepemimpinan, komunikasi internal dan motivasi kerja secara parsial berpengaruh signifikan terhadap kinerja pegawai kantor kecamatan Grogol Petamburan Jakarta Barat.

\section{METODE PENELITIAN}

\section{Objek Penelitian}

Pada penelitian ini yang menjadi objek penelitian adalah karyawan perbankan yang ada di Purwokerto.

\section{Jenis Data}

Penelitian ini menggunakan data yang diperoleh melalui responden, dimana responden memberikan respon tertulis sebagai tanggapan atas pernyataan yang diberikan. Adapun jenis data yang digunakan dalam penelitian ini adalah. Gaya Kepemimpinan (X1) Komunikasi Internal (X2) Motivasi Kerja (X3) Kinerja Pegawai (Y)

\section{Data Primer}

Data primer dalam penelitian ini mengenai pendapat responden tentang gaya kepemimpinan, komunikasi internal, motivasi kerja, dan kinerja pegawai yang diperoleh secara langsung dari responden dengan memberikan tanggapan atas pernyataan yang terdapat dalam kuesioner.

2. Data Sekunder

Data sekunder dalam penelitian ini diperoleh secara tidak langsung melalui perantara (diperoleh dan dicatat oleh pihak lain). Dalam penelitian ini, data sekunder yang dimaksud adalah data mengenai gambaran umum karyawan perbankan. Teknik pengukuran data yang digunakan adalah skala likert. Teknik ini merupakan pemberian skala pernyataan sikap yang menggunakan distribusi respon sebagai dasar penentuan nilai skalanya. Selanjutnya pilihan jawaban responden diberi skor.

Skor yang diberikan atas masing-masing tanggapan adalah berkisar dari 1 sampai 5 dengan pilihan jawaban yang terdiri dari Sangat Tidak Setuju (STS), Tidak Setuju (TS), Netral (N), Setuju (S) dan Sangat Setuju (SS).

\section{Populasi dan Teknik Penentuan Sampel}

Populasi dalam penelitian ini yaitu karyawan perbankan umum dan syariah yang ada di kota Purwokerto.

\section{Variabel Penelitian}

Dalam Penelitian ini terdapat 4 variabel yaitu 3 variabel bebas yang terdiri dari Gaya Kepemimpinan (X1), Komunikasi Internal (X2), serta Motivasi Kerja (X3) dan 1 variabel terikat yaitu Kinerja $(\mathrm{Y})$.

Indikator yang digunakan untuk masing-masing variabel antara lain untuk

Gaya Kepemimpinan (X1) terdiri dari 4 indikator,

Komunikasi Internal (X2) terdiri dari 5 indikator,

Motivasi Kerja (X3) terdiri dari 5 indikator dan

Kinerja $(Y)$ terdiri dari 6 indikator.

\section{Metode Analisis Data Uji Validitas}

Uji validitas digunakan untuk mengukur valid tidaknya suatu kuesioner. Suatu kuesioner dikatakan valid jika pertanyaan mampu untuk mengungkapkan sesuatu 
yang akan diukur oleh kuesioner tersebut (Ghozali, 2013). Uji validitas dilakukan dengan menggunakan metode Pearson Correlation, yang merupakan korelasi antara skor item dengan skor total masing-masing variabel. Secara statistik, angka korelasi bagian total yang diperoleh harus dibandingkan dengan angka dalam tabel $r$ tabel. Apabila nilai $r$ hitung lebih besar dari $r$ tabel maka kuesioner tersebut dapat dikatakan valid dan sebaliknya.

\section{Uji Reliabilitas}

Uji reliabilitas yaitu uji untuk menunjukkan sejauh mana suatu hasil pengukuran relatif konsisten apabila pengukuran diulangi dua kali atau lebih. Uji reliabilitas dilakukan dengan menggunakan teknik Alpha Cronbach dan membandingkan koefisien Alpha dengan koefisien R yaitu 0,6 (Ghozali, 2013). Bila koefisien Alpha lebih besar dari koefisien R, maka alat penelitian (kuesioner) yang diuji adalah reliabel dan sebaliknya.

\section{Uji Asumsi Klasik}

Uji ini dilakukan untuk memenuhi syarat agar syarat persamaan yang diperoleh model regresi dapat diterima. Uji asumsi klasik ini terdiri dari:

1. Uji Normalitas, Model regresi yang memenuhi uji normalitas jika dalam grafik P-P Plot datanya menyebar di sekitar garis diagonal dan mengikuti arah garis diagonal.

2. Uji Multikolinieritas, untuk menguji apakah pada model regresi ditemukan adanya korelasi antar variabel bebas. Adapun pedoman suatu model regresi yang bebas multikolinieritas adalah VIF di bawah 10 dan tolerance lebih besar dari 0.1.

3. Uji Heteroskedastisitas, untuk menguji apakah pada model regresi ditemukan adanya ketidaksamaan varian dari suatu pengamatan ke pengamatan lain. Model regresi yang baik jika dalam grafik scatterplot tidak ada pola yang jelas, serta titiktitik menyebar diatas dan dibawah angka 0 pada sumbu $\mathrm{Y}$.

4. Uji Autokorelasi, salah satu cara untuk mendeteksi masalah autokorelasi adalah uji Durbin Watson $(\mathrm{DW})$. Jika koefisien $\mathrm{DW}=2$, maka tidak terjadi autokorelasi sempurna. Jika nilai DW diantara 1,5 sampai 2,5 maka data tidak mengalami autokorelasi, tetapi jika nilai DW 0 sampai 1,5 disebut memiliki autokorelasi positif, dan jika DW lebih besar dari 2,5 sampai 4 disebut memiliki autokorelasi negative.

\section{Analisis Regresi Linier Berganda}

Analisis regresi bertujuan untuk mengetahui pengaruh variabel bebas terhadap variabel terikat. Analisis ini menunjukkan bahwa variabel terikat akan bergantung (terpengaruh) pada lebih dari satu variabel bebas. Persamaan regresi linier berganda dalam penelitian ini adalah

sebagai berikut:

$$
K P=a+b 1 G K+b 2 K I+b 3 M K+e
$$

Dimana:

$\mathrm{KP} \quad=$ Kinerja pegawai

a $=$ Konstanta

b1,b2,b3 = Koefisien regresi

GK = Gaya kepemimpinan

$\mathrm{KI}=$ Komunikasi internal

MK = Motivasi kerja

e $=$ Error 


\section{Uji Simultan}

Uji Simultan (Uji F) dilakukan untuk mengetahui seberapa jauh pengaruh variabel bebas $(\mathrm{X})$ terhadap variabel terikat $(\mathrm{Y})$ secara simultan. Adapaun kriteria penentuan nilai uji $\mathrm{F}$ adalah dengan tingkat signifikan sebesar $5 \%$ dengan degree of freedom (derajat keyakinan) df1 $=\mathrm{k}-1$ dan $\mathrm{df} 2=\mathrm{n}-\mathrm{k}-1$ akan diperoleh nilai $\mathrm{F}$ tabel dan kemudian dibandingkan dengan nilai $\mathrm{F}$ hitung.

\section{Koefisien Determinasi (R2)}

Koefisien determinasi dalam regresi linier berganda digunakan untuk mengetahui persentase sumbangan pengaruh variabel bebas (X1, X2, X3) secara

serentak terhadap variabel terikat $(\mathrm{Y})$. Koefisien ini menunjukkan seberapa besar persentase variasi variabel bebas yang digunakan mampu menjelaskan variasi variabel terikat.

\section{Uji Parsial}

Uji ini digunakan untuk mengetahui apakah variabel-variabel bebas dapat mempengaruhi variabel terikat, maka diperlukan pengujian hipotesis statistik secara parsial dengan menggunakan Uji Parsial (Uji t). Uji ini membandingkan antara nilai t hitung dari masing-masing variabel dengan t tabel. Jika t hitung lebih besar dari $t$ tabel, maka Ho ditolak dan Ha diterima. Jika t hitung lebih kecil dari t tabel, maka Ho diterima dan Ha ditolak.

\section{HASIL DAN PEMBAHASAN Karakteristik Responden}

Dalam penelitian ini, karakteristik responden terdiri dari jenis kelamin, usia, pendidikan terakhir dan masa kerja. Hasil penelitian dapat dilihat pada gambar berikut ini.

\section{Uji Validitas}

Menurut Ghozali (2006), uji validitas digunakan untuk mengukur valid tidaknya suatu kuesioner. Uji signifikansi dilakukan dengan membandingkan nilai $r$ hitung dengan $r$ tabel untuk degree of freedom $(\mathrm{df})=\mathrm{n}-2$. Besar $r$ tabel pada penelitian iniadalah sebesar $((\mathrm{n}-2) ; \mathrm{a})=((15-2) ; 5 \%)=0.514$. Besar $r$ tabel dapat dilihat pada lampiran yaitu pada $r$ tabel product momentdengan tingkat signifikan $5 \%$. Hasil uji validitas menunjukkan bahwa semua indikator yang dipakai dalam penelitian ini dinyatakan valid.

\section{Uji Reliabilitas}

Uji reliabilitas dilakukan dengan menggunakan teknik Cronbach Alpha. Dari hasil pengolahan data diperoleh hasil yang menunjukkan bahwa variabel yang dipakai dalam penelitian ini adalah reliabel. Hal ini ditunjukkan dengan besarnya nilai Cronbach Alpha per variabel lebih besar dari standar alpha 0.6 (Ghozali, 2001). Hasil uji reliabilitas dari semua variabel menunjukkan bahwa semua variabel memiliki nilai Cronbach Alpha lebih besardari 0.6, maka semua variabel dinyatakan reliabel. 


\section{Deskripsi Variabel Penelitian}

Deskripsi variabel penelitian menggambarkan nilai masing-masing variabel dilihat dari mean, standar deviasi, median, modus, minimum dan maksimun. Deskripsi variabel penelitian yang akan dianalisis dalam penelitian ini terdiri darivariabel gaya kepemimpinan, komunikasi internal, motivasi kerja dan kinerja.

\section{Variabel Gaya Kepemimpinan}

Variabel gaya kepemimpinan pada penelitian ini diukur dengan menggunakan 4 pernyataan yang mempresentasikan indikator-indikator dari variabel tersebut. Hasil penelitian yang diperoleh dari pengumpulan data tentang gaya kepemimpinan (GK), skor terendah (minimum) adalah 10 dan skor tertinggi (maksimum) adalah 20, dengan range sebesar 10, sedangkan jumlah data sebanyak 35. Mean 17.11, median 18, modus 18, standar deviasi 2.610 dan sum 599.

\section{Variabel Komunikasi Internal}

Variabel komunikasi internal pada penelitian ini diukur dengan menggunakan 5 pernyataan yang mempresentasikan indikator-indikator dari variabel tersebut. Hasil penelitian yang diperoleh dari pengumpulan data tentang komunikasi internal $(\mathrm{KI})$, skor terendah (minimum) adalah 14 dan skor tertinggi (maksimum) adalah 25, dengan range sebesar 11, sedangkan jumlah data sebanyak 35. Mean 20.83, median 21, modus 21, standar deviasi 2.256 dan sum 729 .

\section{Variabel Motivasi Kerja}

Variabel motivasi kerja pada penelitian ini diukur dengan menggunakan 5 pernyataan yang mempresentasikan indikator-indikator dari variabel tersebut. Hasil penelitian yang diperoleh dari pengumpulan data tentang motivasi kerja (MK), skor terendah (minimum) adalah 17 dan skor tertinggi (maksimum) adalah 25, dengan range sebesar 8 , sedangkan jumlah data sebanyak 35. Mean 20.97, median 20, modus 20, standar deviasi 2.256 dan sum 734 .

\section{Variabel Kinerja}

Variabel kinerja pada penelitian ini diukur dengan menggunakan 6 pernyataan yang mempresentasikan indikator-indikator dari variabel tersebut. Hasil penelitian yang diperoleh dari pengumpulan data tentang kinerja (KP), skor terendah (minimum) adalah 17 dan skor tertinggi (maksimum) adalah 25, dengan range sebesar 8 , sedangkan jumlah data sebanyak 35 . Mean 21.46, median 22, modus 22, standar deviasi 1.868 dan sum 757.

\section{Uji Asumsi Klasik}

Uji ini dilakukan untuk memenuhisyarat agar syarat persamaan yang diperoleh model regresi dapat diterima. Uji asumsi klasik terdiri dari uji normalitas, multikolinieritas, heterokedastisitas dan autokorelasi.

\section{Regresi Linier Berganda \\ Pengaruh Simultan}

Analisis regresi berganda bertujuan untuk mengetahui pengaruh variabel bebas terhadap variabel terikat. Data dalam penelitian ini dan hasil persamaan regresi sebagai berikut. 


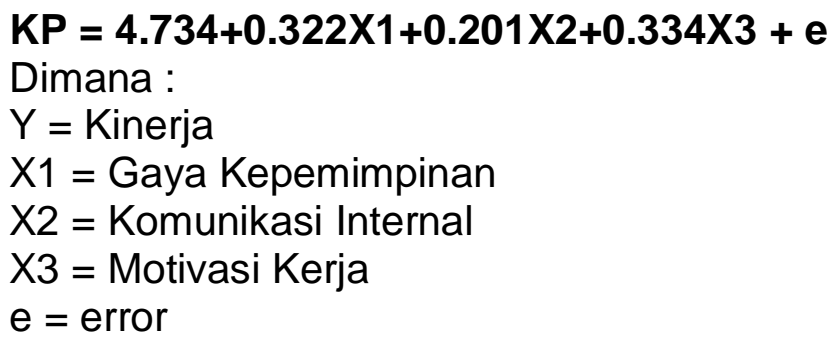

Uji $\mathrm{F}$ menunjukkan apakah semua variabel bebas mempunyai pengaruh secara bersama-sama atau simultan terhadap varaibel terikat (Kuncoro, 2001).

Berdasarkan hasil perhitungan statistik melalui SPSS versi 16 dapat diketahui bahwa nilai $F$ hitung sebesar 29.750 lebih besar dari nilai $F$ tabel (2.72) dan nilai signifikan 0.000. Maka kesimpulan yang dapat diambil adalah $\mathrm{Ho}$ ditolak dan $\mathrm{Ha}$ diterima, yang artinya gaya kepemimpinan, komunikasi internal, dan motivasi kerja secara simultan berpengaruh signifikan terhadap kinerja pegawai kantor Kecamatan Grogol Petamburan Jakarta Barat.

\section{Koefisien Determinasi (R2)}

Koefisien ini menunjukkan seberapa besar persentase variasi variabel bebas yang digunakan mampu menjelaskan variasi variabel terikat. Berdasarkan hasil perhitungan statistik melalui SPSS dapat diketahui bahwa nilai $R$ Square sebesar 0.742 . Hal ini menunjukkan bahwa persentase sumbangan pengaruh variabel bebas (gaya kepemimpinan, komunikasi internal, motivasi kerja) terhadap variabel terikat (kinerja) sebesar $74.2 \%$. Sedangkansisanya sebesar $25.8 \%$ dipengaruhi atau dijelaskan oleh variabel lain misalnya budaya organisasi, lingkungan organisasi, disiplin kerja.

\section{Pengaruh Parsial}

Untuk mengetahui apakah variabel independen dapat mempengaruhi variabel dependen, maka diperlukan pengujian hipotesis statistik secara parsial dengan menggunakan uji t ( $t$ test).

Hipotesis:

Ho: Gaya kepemimpinan, komunikasi internal, dan motivasi kerja secaraparsial tidak berpengaruh signifikan terhadap kinerja karyawan perbankan.

$\mathrm{Ha}$ : Gaya kepemimpinan, komunikasi internal, dan motivasi kerja secara parsial berpengaruh signifikan terhadap kinerja karyawan perbankan.

Berdasarkan hasil perhitungan statistik dapat diketahui bahwa nilai t hitung variabel gaya kepemimpinan (GK) sebesar 4.357,komunikasi internal (KI) sebesar 2.230 dan motivasi kerja (MK) sebesar 3.814. Hasil t hitung dari masing-masing variabel semuanya memiliki nilai yang lebih besardari t tabel sebesar 1.689 . Dengan menggunakan taraf signifikan sebesar 5\%(0.05), nilai signifikan tersebut lebih kecildari batas signifikan yang digunakan, maka kesimpulan yang diambil adalah Ho ditolak dan $\mathrm{Ha}$ diterima yang berarti gaya kepemimpinan, komunikasi internal dan motivasi kerja secara parsial berpengaruh signifikan terhadap kinerja karyawan perbankan. 


\section{Variabel yang Paling Dominan}

Dari ketiga variabel bebas dalam penelitian ini, variabel yang paling dominan dalam memengaruhi kinerja pegawai adalah gaya kepemimpinan (GK) sebesar 0.449, diikuti oleh variabel motivasi kerja (MK) sebesar 0.403 dan komunikasi internal (KI) sebesar 0.255.

\section{KESIMPULAN}

\section{Kesimpulan}

Berdasarkan hasil analisis sebelumnya, maka dapat disimpulkan bahwa.

1. Gaya kepemimpinan, komunikasi internal, dan motivasi kerja secara simultan berpengaruh signifikan terhadap kinerja karyawan perbankan

2. Gaya kepemimpinan, komunikasi internal, dan motivasi kerja secara parsial berpengaruh signifikan terhadap kinerja karyawan perbankan

3. Variabel yang paling dominan dalam memengaruhi kinerja karyawan perbankan variabel gayakepemimpinan, diikuti oleh variabelmotivasi kerja dan komunikasi internal.

\section{DAFTAR PUSTAKA}

Bashor, Choirul. 2007. "Pengaruh Motivasi Kerja terhadap Kinerja Karyawan PT. Semen Gresik. Tuban dengan Variabel Moderator Etos Kerja Spiritual”. Jurnal Manajemen, Akuntansi dan Bisnis. Vol.5. No.3.

Bitterl, Lester R. dan John W. Newstrom. 1994. Pedoman Bagi Penyelia (Terjemahan). Pustaka Binaman Pressindo. Jakarta.

Buchori, Zainun. 2004. Manajemen dan Motivasi. Balai Aksara. Jakarta.

Ciptono, Agus dan Zulian Yamit. 2005. "Pengaruh Motif Berprestasi, Motif Berafiliasi dan Motif Kekuasaan terhadap Kinerja Pekerja Pada Kantor BRI Unit Cabang Sleman. Kajian Bisnis dan Manajemen. Edisi Khusus on Human Resources. 59-72.

Daft, Richard L. 2001. Organization Theory and Design. South Westen College Publishing.

Davis, Keith dan John W. Newstrom. 1985. Human Behaviour at Work : Organizational Behaviour. Mc.Grav-Hill Inc. New York.

Deddy, Mulyana. 2005. Ilmu Komunikasi: Suatu Pengantar. Remaja Rosdakarya. Bandung.

Djati, Sundring Pantja. 1999. "Pengaruh Variabel-Variabel Motivasi terhadap Produktivitas Tenaga Kerja Karyawan pada Industri Rumah Tangga di Kabupaten Sidoarjo". Jurnal Manajemen dan Kewirausahaan. Vol.1 No.1. 2235.

George, J.M., and G.R. Jones. 2002. Understanding and Managing Organizational gBehavior. Prentice Hall. New Jersey.

Ghozali, Imam. 2013. Analisis Multivariate. Badan Penerbit UNDIP. Semarang.. 2005. Aplikasi Analisis Multivariate dengan Program SPSS. Badan Penerbit UNDIP. Semarang.

Gibson, James L., John M. Ivancevich dan James H. Donnelly, Jr. (1996). Organisasi, Perilaku, Struktur, Proses, (Alih Bahasa Nunuk Adiarni). Penerbit Binarupa Aksara. Jakarta. 
Hadari, Nawawi. 2003. Manajemen Sumber Daya Manusia untuk Bisnis yang Kompetitif. Gajah Mada University Press. Yogyakarta.

Handoko, T. Hani. 1992. Manajemen Personalia dan Sumber Daya Manusia. Edisi Kedua. BPFE UGM.Yogyakarta.

Harlen, H. 2009. "Pengaruh Motivasi, Kemampuan dan Lingkungan Organisasi terhadap Kinerja Karyawan (Studi Pada PT. XYZ, Perusahaan Perkebunan Swasta Nasional di Pekanbaru, Riau)". Jurnal Aplikasi Manajemen. Vol.7 No. 2. 293-304.

Hasibuan, Malayu SP. 1995. Manajemen Sumber Daya Manusia Dasar dan Kunci Keberhasilan. Haji Mas Agung. Jakarta.

Heidjerahman dan Su'ad Husnan. 1996. Manajemen Personalia. BPFE UGM. Yogyakarta.

Hersey, Paul Kenneth, H. Blanchard, dan Dewey E. Johnson. 2001. Management of Organization. New Jersey: Prentice Hall International Inc. House, R.J. 1971. A Path Goal Theory of Leader Effectiveness. Administrative Science Quarterly. 321-338.

Jubaedah, Edah. 2009. "Analisis Hubungan Gaya Kepemimpinan dan Kompetensi Komunikasi dalam Organisasi”. Jurnal IImu Administrasi. Vol.VI. No.4. 371380.

Kartika, Endo Wijaya dan Thomas S. Kaihatu. 2010. "Analisis Pengaruh Motivasi Kerja terhadap Kepuasan Kerja (Studi Kasus Pada Karyawan Restoran Di Pakuwon Food Festival Surabaya)". Jurnal Manajemen dan Kewirausahaan. Vol.12. No.1.100-112.

Kuncoro, Mudrajad. 2001. Metode Kuantitatif Teori dan Aplikasi untuk Bisnis dan Manajemen. UPP AMP YKPB.

Lewa, Eka Idham Lip K. 2005. "Pengaruh Kepemimpinan, Lingkungan Kerja fisik dan Kompensasi terhadap Kinerja Karyawan di PT. Pertamina (Persero) Daerah Operasi Hulu Jawa Bagian Barat Cirebon". Kajian Bisnis dan Manajemen. Edisi Khusus on Human Resources. ISSN:1978-3116. 195-216.

Lussier, Robert N. 1996. Human Relation in Organization;a skill Building Approach. Richard D. Irwin Inc. Luthans, F. 2006. Perilaku Organisasi. Edisi Kesepuluh. Penerbit Andi. Jakarta.

Mangkunegara, Anwar Prabu. 2007. Evaluasi Kinerja Sumber DayaManusia. Refika Aditama. Bandung.

Maslow, A. 1994. Motivasi dan Kepribadian, Terjemahan. Pustaka Binaman Pressindo. Jakarta.

Mathis, R.L dan Jackson. 2001. Human Resource Management (Terjemahan) Buku 1. Edisi Kesembilan. Salemba Empat. Jakarta.

Muhammad, Arni. 2001. Komunikasi Organisasi. Bumi Aksara. Jakarta.

Mutmainnah, Sri. 2008. "Pengaruh Motivasi dan Disiplin Kerja terhadap Kinerja Karyawan Pada PT. Panen Lestari Internusa Medan”. Jurnal IImu Manajemen dan Bisnis. Vol.III. No.1. 26-29.Universitas Negeri Medan.

Nasution, Mulia. 1994. Manajemen Personalia, Aplikasi dalam Perusahaan. Djambatan. Jakarta.

Nitisemito, Alex. 1998. Manajemen Personalia (Manajemen Sumber Daya Manusia). Ghalia Indonesia.Jakarta.

Nursada, I., Alhabsji, T., Al Musadieq. 2008. "Pengaruh Motivasi Kerja, Kemampuan Kerja, Gaya Kepemimpinan Situasional dan Disiplin Kerja terhadap Prestasi Kerja Karyawan". Jurnal Ekonomi dan Bisnis. Vol.6. No.2. 108-115. 
Prawirosentono, Suyadi. 1999. Manajemen Sumber Daya Manusia: Kebijakan Kinerja Karyawan. BPFE. Yogyakarta.

Ruvendi, Ramlan. 2005. "Imbalan dan Gaya Kepemimpinan Pengaruhnya terhadap Kepuasan Kerja Karyawan di Balai Besar Industri Hasil Pertanian Bogor". Jurnal Ilmiah Binaniaga. Vol.01. No.1 17-26.

Santoso, Singgih. 2000. Buku Latihan SPSS Statistik Parametrik. Elex Media Komputindo. Jakarta.

Siagian, Sondang P. 1993. Manajemen Sumber Daya Manusia. PT. Toko Gunung Agung. Jakarta.. 1995. Teknik Menumbuhkan dan Menekan Perilaku

Sudiro, Achmad dan Nona F. A. Sumanang. 2005. "Pengaruh Komunikasi yang Efektif dalam Organisasi terhadap Kepuasan Kerja Karyawan Pada Bagian Produksi (Studi Pada PT. Tirta Investama Pandaan). Jurnal Aplikasi Manajemen. Vol.3 No.3. 204-211.

Sudardjat, Giri Yani Djaja. 2007. "Hubungan Gaya Kepemimpinan dan Insentif terhadap Produktivitas Kerja pada PT. Recapital Securities di Jakarta”. Jurnal Manajemen Publik dan Bisnis. 20-36. 